\title{
KRITERIA PEMBATASAN HAK CIPTA LAGU DALAM PRAKTIK COVERING MELALUI YOUTUBE
}

\author{
Faghlaifi Naim, SH \\ Alumni Fakultas Hukum Universitas Islam Indonesia \\ Contact: sikillpepy@gmail.com
}

Diterima : 12 Des 2018

Direvisi: 11 Januari 2019

Disetujui : 30 Januari 2019

Hak Cipta : ( $) 2019$

Halaman : 22-35

\begin{abstract}
This study aims to find out the Criteria for Song Copyright Restriction in Covering Practices through Youtube. The formulation of the problem proposed is namely: What is The Criteria for Song Copyright Restriction in Covering Practices through Youtube. This study included a normative research typology. This normative legal research is doctrinal legal research. also referred to as library research or document study. It is called doctrinal law research because this research is carried out or aimed only at written regulations or other legal materials.

It is called doctrinal law research because this research is carried out or aimed only at written regulations or other legal materials. Primary legal material is material that has juridical binding powers, such as legislation, court decisions, and agreements. Secondary legal materials are materials that do not have juridical binding powers, such as: draft legislation, literatures, and journals. Tertiary legal materials are complementary to primary data and secondary data, such as dictionaries and encyclopedias. Analysis is carried out with approaches including: legislation, conceptual, historical, comparative, and philosophical. The results of this study indicate that there are criteria for copyright restrictions in the internal YouTube regulations that must be considered to practice music covering.
\end{abstract}

Keywords : Copyrights, Copyrights Limitation, Covering Practice, Youtube 


\section{PENDAHULUAN}

Pada tanggal 16 September tahun 2014 lalu Dewan Perwakilan Rakyat mengesahkan Undangundang Nomor 28 Tahun 2014 tentang Hak Cipta baru yang terdiri 19 Bab dan 126 Pasal. Salah satu yang diatur dalam Undangundang tersebut adalah hak bagi pemegang hak cipta untuk mendapatkan perlindungan ekonomi atas ciptaanya.

Dengan disahkannya UU No. 28 Tahun 2014 ini diharapkan kedepannya pelaku-pelaku seni akan mendapatkan kepastian hukum akan karya-karyanya. Apalagi sistem HKI akan selalu memberikan pengamanan akan suatu karya dari karya-karya yang dihasilkan karena adanya kekayaan pribadi yang dimiliki oleh seseorang.

UU No. 28 Tahun 2014 mengenal dua jenis hak yang terkandung dalam suatu ciptaan, yaitu hak cipta (copyrights) dan hak terkait (neighbouring rights). Kedua jenis hak ini merupakan bagian dari hak eksklusif yang melekat bagi pencipta, pemegang hak cipta dan pemilik hak terkait. (Ashibly, 2016: 51)

Hak cipta adalah hak eksklusif pencipta yang timbul secara otomatis berdasarkan prinsip deklaratif setelah suatu ciptaan diwujudkan dalam bentuk nyata tanpa mengurangi pembatasan sesuai dengan ketentuan peraturan perundang - undangan.

Ada 2 (dua) bagian besar hak eksklusif yang terkandung di dalam hak cipta, yaitu hak moral dan dan hak ekonomi. Hak moral (moral rights) adalah hak yang melekat pada

diri pencipta (termasuk pelaku pertunjukkan) yang tidak dapat dihilangkan atau diahapus dengan alasan apapun. Antara pencipta dan ciptaannya ada sifat kemanunggalan atau dengan kata lain ada hubungan integral di antara keduanya. (Nainggolan, 2011: 54)

Konsep hak moral ini berasal dari sistem hukum continental, yaitu dari Perancis. Hak moral sebagaimana dimaksud ayat (1) UU No. 28 Tahun 2014 tidak dapat dialihkan selama pencipta masih hidup, tetapi pelaksanaa hak tersebut dapat dialihkan dengan wasiat atau atau sebab lain sesuai dengan ketentuan perundangundangan setelah Pencipta meninggal dunia. Hak moral suatu hak cipta dapat mencakup hak untuk mencantumkan nama pencipta dalam ciptaannya dan hak untuk mengubah judul/atau isi ciptaan. (Djumhana \& Djubaedillah, 1997: 91)

Pengaturan mengenai hak ekonomi pencipta dalam UU No. 28 Tahun 2014 diatur dalam Pasal 8 yang menyebutkan "Hak ekonomi merupakan hak eksklusif pencipta 
atau pemegang hak cipta untuk mendapatkan manfaat ekonomi atau ciptaan". Selanjutnya dalam Pasal 9 ayat (1) UU No. 28 Tahun 2014 menyebutkan bahwa "pencipta atau pemegang hak cipta sebagaimana dimaksud dalam Pasal 8 UU No. 28 Tahun 2014 memiliki hak ekonomi untuk melakukan : (Ashibly, 2016: 72)

1. Penerbitan ciptaan;

2. Penggandaan ciptaan dalam segala bentuknya;

3. Penerjemahan ciptaan;

4. Pengadaptasian, pengaransemenan, atau pentransformasian ciptaan;

5. Pendistribusian ciptaan atau salinannya;

6. Pertunjukan ciptaan;

7. Pengumuman ciptaan;

8. Komunikasi ciptaan; dan

9. Penyewaan ciptaan.

Berikutnya setiap orang yang melaksanakan hak ekonomi sebagaimana dimaksud pada ayat (1) UU No. 28 Tahun 2014 wajib mendapatkan izin pencipta atau pemegang hak cipta. menurut Pasal 8 ayat 2 UU No. 28 Tahun 2014 dinyatakan bahwa Setiap orang yang melakukan penggandaan dan/atau penggunaan secara komersial ciptaan (Pasal 8 ayat 3). Selanjutnya, Pasal 11 ayat 1 dan ayat 2 UU No. 28 Tahun 2014 menyatakan "Hak ekonomi untuk melakukan pendistribusian ciptaan atau salinannya sebagaimana dimaksud dalam Pasal 9 ayat (1) huruf e tidak berlaku terhadap ciptaan atau salinannya yang telah dijual atau yang telah dialihkan kepemilikan ciptaan kepada siapapun. Hak ekonomi untuk menyewakan ciptaan tidak berlaku terhadap program komputer dalam hal program komputer tersebut bukan merupakan objek esensial dari penyewaan. (Ashibly, 2016: 72)

Berdasarkan hak-hak ekonomi yang dipunyai, memungkinkan seorang pencipta mengeksploitasi suatu karya cipta sedemikian rupa untuk memperoleh keuntungankeuntungan ekonomi, sehingga perlu dilindungi secara memadai. Terkandung di dalam suatu karya cipta yang memiliki nilai-nilai ekonomis. Oleh karena itu, suatu ciptaan jika tidak

dikelola secara tertib berdasarkan seperangkat kaidah-kaidah hukum, dapat menimbulkan sengketa antar pemilik hak cipta dengan pengelola (pemegang) hak cipta atau pihak lain yang melanggarnya. Untuk pengaturannya diperlukan seperangkat ketentuan-ketentuan hukum yang efektif dari segala kemungkinan pelanggaran oleh mereka yang tidak berhak atas hak cipta yang dimiliki seseorang. (Margono, 2010: 4)

Berikut ini jangka waktu perlindungan hak cipta atas ciptaan menurut Pasal 58 UU No. 28 Tahun 2014. Perlindungan Hak Cipta atas Ciptaan: (Hidayah, 2017: 36)

1) Buku, pamphlet, dan semua hasil karya tulis lainnya;

2) Ceramah, kuliah, pidato, dan hasil ciptaan sejenis lainnya;

3) Alat peraga yang dibuat untuk kepentingan 
pendidikan dan ilmu pengetahuan;

4) Lagu atau musik dengan atau tanpa teks;

5) Drama, drama musikal, tari, koreografi, pewayangan dan ilmu pantonim;

6) Karya seni rupa dalam segala bentuk seperti lukisan, gambar, ukiran, kaligrafi, seni pahat, patung, atau kolase;

7) Karya arsitektur;

8) Peta;

9) Karya seni batik atau seni motif lain.

Berlaku selama hidup pencipta dan terus berlangsung selama 70 tahun setelah pencipta meninggal dunia, terhitung mulai tanggal 1 Januari tahun berikutnya. Waktu perlindungan bagi pencipta perorangan berbeda dengan badan hukum. Jika badan hukum waktu perlindungannya adalah 50 tahun sejak pertama kali ciptaan diumumkan.

Pasal 59 UU No 28 Tahun 2014 mengatur bahwa Hak Cipta atas Ciptaan: (Hidayah, 2017: 37)

1) Karya fotografi;

2) Potret;

3) Karya sinematografi;

4) Permainan video;

5) Program Komputer;

6) Perwajahan karya tulis;

7) Terjemahan, tafsir, saduran, bunga rampai, basis data, adaptasi, aransemen, modifikasi dan karya lain dari hasil transformasi;

8) Terjemahan, adaptasi, aransemen, transformasi, atau modifikasi ekspresi budaya tradisional;
9) Kompilasi ciptaan atau data, baik dalam format yang dapat dibaca dengan program computer atau media lainnya;

10)Kompilasi ekspresi budaya tradisional selama kompilasi tersebut merupakan karya yang asli, berlaku selama 50 tahun sejak pertama kali ciptaan diumumkan.

Jangka waktu perlindungan bagi pemegang hak-hak terkait berdasarkan Pasal 60 Undangundang No 28 Tahun 2014 adalah : (Hidayah, 2017: 37)

1) Pelaku, berlaku selama 50 tahun sejak karya tersebut pertama kali dipertunjukkan atau dimasukkan ke dalam fonogram atau media audiovisual

2) Produser rekaman suara (fonogram), berlaku selama 50 tahun sejak karya tersebut selesai direkam (difiksasi).

3) Lembaga penyiaran, berlaku selama 20 tahun sejak karya siaran tersebut pertama kali disiarkan.

Era globalisasi ditandai dengan perkembangan teknologi dan ilmu pengetahuan yang sangat pesat. Perkembangan teknologi dan ilmu pengatahuan berakibat adanya konvergensi dari keduanya berupa revolusi industri. Kelanjutan konvergensi teknologi dan ilmu pengetahuan pada akhirnya membawa dunia ini kepada era yang dikenal dengan konvergensi teknologi telekomunikasi, media, 
dan informatika. (Riswandi, 2009: 104)

Di era digital ini sarana teknologi sangat memiliki peranan yang sangat vital, terutama teknologi yang berkaitan dengan penyebaran informasi seperti internet. Dalam hitungan menit, bahkan detik melalui internet setiap individu akan disuguhi dengan berbagai informasi. (Riswandi, 2009: 105)

Teknologi digital telah mengubah peta dunia musik, termasuk di Indonesia. Internet dan teknologi digital seperti pisau bermata dua yang selain memberikan dampak positif bagi musik, juga memberi dampak kurang menguntungkan. (Tajudin, 2015)

Keuntungan pertama yang dunia musik peroleh dari era digital adalah akses yang jauh lebih luas pada referensi musik. Pada era 1990-an ke bawah, akses pada referensi musik sangat terbatas. Orang hanya mendapatkan musik dari sumber utama seperti televisi, radio, toko musik. Sedangkan pada era 2000-an, orang bisa mengakses musik apapun, yang teraneh sekalipun, di sudut dunia terjauh. Hal ini membuat para musisi memiliki referensi yang kaya dan luas. (Tajudin, 2015)

Akibatnya, muncul banyak musisi baru yang memiliki kekayaan bunyi. Mereka mengeksplorasi banyak alat musik dan memiliki karya-karya yang tidak biasa. Anak-anak muda yang jenius di bidang musik ini tidak lagi mengekor pada senior-senior
mereka.Teknologi digital juga membuat mereka lebih mudah merekam musik yang mereka buat. Perekaman menjadi lebih sederhana dan murah. Ini membuat siapa pun bisa membuat rekaman atau demo karya mereka. Bahkan mereka bisa melakukannya di rumah. (Tajudin, 2015)

Dengan teknologi digital pula karya-karya itu lebih mudah untuk disebar ke seluruh dunia. Situssitus seperti MySpace pernah populer untuk mempublikasikan karya musisi muda ini. Lalu muncul Youtube dan lain sebagainya. (Tajudin, 2015)

Implikasinya adalah kemunculan perusahaan label rekaman alternatif, bukan major label. Merekalah yang kemudian memproduksi atau mendistribusikan karya-karya alternatif. Kemunculan mereka mendobrak dinding tebal yang selama ini menghalangi musisi dengan konsep berbeda untuk berkarya. (Tajudin, 2015)

Namun di sisi lain, teknologi digital juga membawa dampak buruk. Mudahnya penyalilan file membuat lagu atau karya musik bisa berpindah tangan dan digandakan dengan begitu cepat dan masif. Akibatnya, karya musik tidak terlindungi. Pembajakan merajalela, copyright sudah di bibir jurang. Orang tidak lagi membeli $\mathrm{CD}$, sejumlah toko musik tutup, musisi tidak lagi mendapat royalti dari lagu yang diputar penggemarnya. (Tajudin, 2015) 
Dengan perkembangan teknologi yang sangat pesat tersebut, negara - negara di seluruh bagian dunia dituntut untuk bisa mengikuti tren tersebut agar tidak tertinggal dari negara lainnya, diantaranya adalah perkembangan Internet.

Sejarah internet terlahir dikala lembaga riset dalam hal ini The Advanced Research Projects Agency (ARPA) dari Departemen Pertahanan Amerika Serikat mengembangkan jaringan komputer yang dikenal dengan ARPA NET. Jaringan ini dihubungkan hanya untuk system komputer niliter dan pemerintahan. (Riswandi, 2009: 120-121)

Internet mengalami perkembangan yang dulunya hanya diperuntukkan oleh kebutuhan militer saja sekarang dapat digunakan untuk keperluan publik, disaat itulah batas - batas antar negara seperti tersamarkan karena seluruh warga negara dari berbagai belahan dunia dapat berkomunikasi satu sama lain tanpa harus mengunjungi negara yang bersangkutan.

Seiring dengan berkembangnya Internet, begitupula dengan konten - konten dan fasilitas di dalamnya, dari mulai dipergunakan sebagai media untuk mencari informasi - informasi terntentu,kegiatan mengunduh dan mengunggah, atau seringkali biasa disebut download dan upload, sampai dengan sarana untuk jual -beli, jasa - jasa tertentu, penyaluran kreativitas baik berbentuk Gambar, Audio, maupun Video. Salah satunya adalah Youtube.

Youtube merupakan sebuah portal website yang yang menyediakan layanan video sharing. Pengguna yang telah mendaftar bisa mengunggah video miliknya ke server Youtube agar dapat dilihat oleh khalayak internet di seluruh dunia. Dari video-video yang telah diunggah itulah pengguna Youtube mendapatkan keuntungan berupa uang yang dibayarkan oleh Youtube secara transfer ke rekening mereka masing-masing, dengan syarat semakin banyak jumlah penonton video yang mereka unggah, maka akan semakin banyak pula jumlah uang yang akan mereka dapatkan dari pihak Youtube. (Hasyim, 2008)

Situs Youtube didirikan oleh mantan pekerja PayPal, Steve Chen, Chad Hurley dan Jawed Karim pada Februari 2005. Dikutip dari Wikipedia, situs ini kemudian beralih menjadi milik Google pada akhir tahun 2006 hingga saat ini.

Covering musik adalah membawakan ulang sebuah lagu yang sebelumnya pernah direkam dan dibawakan penyanyi/artis lain. Banyak para pengguna Youtube yang mencoba melakukan praktik covering tersebut dengan pengetahuan mengenai hak cipta yang minim, sehingga dapat memunculkan persoalan hukum dikemudian hari.

Kasus yang berkaitan dengan masalah cover adalah The National Music

Publishers' Association vs. Fullscreen. Dimana pada tahun 2013 sekelompok 
perusahaan penerbit musik di Amerika Serikat (salah satunya adalah Warner/Chappell Music milik Warner Music Group) yang diwakili oleh the National Music Publishers' Association, menggugat Fullscreen, salah satu perusahaan pemasok video terbesar ke Youtube yang berkantor di Los Angeles, di pengadilan distrik di Manhattan, Amerika Serikat, dengan alasan bahwa banyak dari video-video pasokan Fullscreen, terutama versi cover dari lagu-lagu hits dari artis-artis mereka, melanggar hak cipta mereka. Hal ini sebagaimana disarikan dari The New York Times, www.nytimes.com, edisi 7 Agustus 2013.

\section{Fullscreen mengklaim dirinya sebagai perusahaan media generasi baru yang membangun sebuah jaringan global melalui channel-channel di Youtube bekerja sama dengan ribuan kreator konten. Menurut Fullscreen, $\quad 15.000$ channel yang mereka wakili total memiliki 200 juta pelanggan dan ditonton lebih dari 2,5 miliar orang per bulannya.}

Di antara video-video Fullscreen yang diputar Youtube adalah versi cover dari lagu-lagu hits beberapa artis penggugat, biasanya dibawakan oleh para amatir atau semi profesional, yang ditampilkan tanpa izin publisher dan pencipta lagu serta tanpa membayar royalti. (Setiawati, 2014)

Pembatasan hak cipta di Indonesia sendiri sebenarnya telah diatur di dalam ketentuan Pasal 43 sampai dengan Pasal 51 UU No. 28 Tahun 2014. Problematikanya adalah apa kriteria pembatasan hak cipta dalam di dalam peraturan internal Youtube itu sendiri?

\section{METODE PENELITIAN}

\section{Jenis Penelitian}

Jenis penelitian yang digunakan adalah Penelitian Hukum Normatif. Penelitian Hukum Normatif adalah penelitian hukum dengan cara meneliti bahan pustaka yang merupakan data sekunder dan disebut juga Penelitian Hukum Kepustakaan, yaitu penelitian terhadap data sekunder. Penelitian jenis ini juga disebut dengan penelitian law in book, penelitian doctrinal, dan penelitian data sekunder. (Soemitro, 1988: 11)

2. Pendekatan Penelitian

Karena penulis menggunakan penelitian hukum normatif, maka pada prinsipnya metode pendekatan yang digunakan antara lain : perundang undangan, konseptual, historis, komparatif, dan filosofis.

3. Objek Penelitian

Objek penelitian pada proposal ini adalah terkait dengan kriteria pembatasan hak cipta lagu dalam praktik covering melalui Youtube.

4. Sumber data Penelitian 
Data yang digunakan oleh penulis di dalam penelitian ini adalah Data Sekunder, Data Sekunder adalah data yang diperoleh dari bahan - bahan hukum primer, sekunder, dan tersier.

\section{Bahan Hukum}

Bahan hukum yang dugunakan dalam penelitian ini adalah bahan hukum primer, bahan hukum sekunder, maupun bahan hukum tersier.

Bahan hukum primer adalah bahan yang mempunyai kekuatan megikat yuridis, seperti peraturan perundangundangan, putusan pengadilan, dan perjanjian.

Bahan hukum sekunder adalah bahan yang tidak mempunyai kekuatan mengikat secara yuridis, seperti: rancangan peraturan perundangundangan, literatut, dan jurnal.

Bahan hukum tersier adalah pelengkap data primer dan data sekunder, seperti kamus dan ensiklopedi.

6. Teknik Pengumpulan Data

Teknik pengumpulan data yang digunakan oleh penulis menggunakan teknik pengumpulan data sekunder, yakni melalui studi kepustakaan dan studi dokumen atau arsip baik data fisik maupun data online.

7. Analisis Data
Penulis pada penelitian ini menggunakan alisis data kualitatif, meliputi kegiatan pengklasifikasian data, editing, penyajian hasil analisis dalam bentuk narasi, dan pengambilan kesimpulan.

\section{HASIL DAN PEMBAHASAN}

Hak cipta adalah bagian dari sekumpulan hak yang dinamakan Hak atas Kekayaan Intelektual (HaKI) yang pengaturannya terdapat dalam ilmu hukum dan dinamika Hukum HaKI. Yang dinamakan Hukum HaKI ini, meliputi suatu bidang hukum yang membidangi hak-hak yuridis dari karya-karya atau ciptaan-ciptaan hasil olah pikir manusia bertautan dengan kepentingan-kepentingan yang bersifat ekonomi dan moral. Bidang yang dicakup dalam hakhak atas kekayaan intelektual sangat luas, karena termasuk di dalamnya semua kekayaan intelektual yang dapat terdiri atas: ciptaan sastra, seni, dan ilmu pengetahuan. (Margono, 2010: 21)

Menurut Pasal 1 UU No. 28 Tahun 2014 terdapat dua jenis hak yang melekat pada suatu ciptaan, yakni hak cipta (copyrights) dan hak terkait (neighboring rights). Kedua jenis hak ini merupakan hak eksklusif yang bersifat ekonomis bagi pencipta, pemegang hak cipta dan pemilik hak terkait. Pada Pasal 1 UU No. 28 Tahun 2014 juga memberikan pengertian tentang hak cipta yakni : 
"Hak Cipta adalah hak eksklusif pencipta yang timbul secara otomatis berdasarkan prinsip deklaratif setelah suatu ciptaan diwujudkan dalam bentuk nyata tanpa mengurangi pembatasan sesuai dengan ketentuan peraturan perundang undangan".

Pengertian "hak eksklusif" menueut penjelasan Pasal 4 UU No. 28 Tahun 2014 adalah hak yang hanya diperuntukkan bagi pencipta, sehingga tidak ada pihak lain yang dapat memanfaatkan hak tersebut tanpa izin pencipta. Pemegang hak cipta yang bukan pencipta hanya memiliki sebagian dari hak eksklusif berupa hak ekonomi.

Ada 2 (dua) bagian besar hak eksklusif yang terkandung di dalam hak cipta, yaitu hak moral dan dan hak ekonomi. Hak moral (moral rights) adalah hak yang melekat pada diri pencipta (termasuk pelaku pertunjukkan) yang tidak dapat dihilangkan atau diahapus dengan alasan apapun. Antara pencipta dan ciptaannya ada sifat kemanunggalan atau dengan kata lain ada hubungan integral di antara keduanya. (Nainggolan, 2011: 54)

Hal ini bukan berarti seseorang tidak dapat memakai / menggunakan karya milik orang lain, akan tetapi penggunaan suatu karya milik orang lain haruslah tidak merugikan kepentingan sang pemilik hak cipta.

Untuk itu dibutuhkan suatu batasan tertentu dalam rangka melindungi kepentingan pemilik hak cipta. Undang - undang di Indonesia melalui UU No. 28 Tahun 2014 telah menetapkan pemabatasan bagi seseorang yang hendak menggunakan karya milik orang lain, yaitu terdapat dalam Pasal 43 sampai dengan Pasal 51 UU No. 28 Tahun 2014. Pembatasan pertama kali diatur dalam Article 9 Berne Convention yang menentukan : (Nainggolan, 2011: 54)

"It shall be a matter for legislation in the countries of union to permit the reproduction does not conflict with a normal expolitation of the work and does not unreasonably prejudice the legitimate interest of the author."

Dalam istilah internasional, dikenal istilah fair use ataupun fair dealing, Konsep fair use dalam konteks hukum hak cipta di Indonesia adalah apabila ada seseorang mengambil karya milik orang lain dalam kerangka kepentingan pendidikan, penelitian, dan karya ilmiah asalkan tidak untuk kepentingan komersial dan juga etikanya. Mencantumkan sumber karya tersebut, maka hal ini dianggap bukan sebagai pelanggaran terhadap hak cipta. (Riswandi, 2009: 145)

Thomas G.Field,jr menyatakan "fair use is one of the most important, and least clear cut, limit or copyright. It permits some use of other's works even without approval." Di Amerika Serikat doktrin fair use juga dikenal. Doktrin ini dikembangkan oleh lembaga peradilan dan sekarang 
ditetapkan dalam statuta yang menyeimbangkan hak dari pencipta dan kepentingan publik. Doktrin fair use di Amerika Serikat dapat dilihat sebagai berikut: (Riswandi, 2009: 145)

"For purposes such as criticism, comment, news reporting, teaching (including multiple copies for classroom use), scholarship, or research, is not infringement of copyright. In determining wether the use made of work in any particular case is a fair use the factors to be fair use considered shall include:

1) the purpose and character of the use, inncluding whether such use is a commercial nature or is nonprofit education purposes;

2) the nature of copyright work;

3) the amount and substansialy of the portion used in relation to the copyrighted work as a whole; and

4) the effect of use upon the potential market value of copyright work.

Di sini dapat dikemukakan bahwa di Amerika Serikat dapat dimaksudkan untuk kritik, komentar, laporan berita, pengajaran, dan penelitian. Dalam penentuannya akan memepertimbangkan pada maksud dan karakter pengguna, meliputi apakah digunakan untuk kepentingan bersifat komersial atau untuk kepentingan pendidikan yang bersifat non profit, sifat dari karya cipta itu sendiri; porsi substansi yang digunakan dalam hubugan dengan karya cipta secara keseluruhan dampak dari pengguna di atas nilai pasar secara potensial atau nilai karya cipta. (Riswandi, 2009: 145)

Pembatasan (limitation) Hak Eksklusif juga berlaku bagi hak terkait dengan hak cipta, yaitu untuk tujuan pembelajaran (teaching), penelitian ilmu pengetahuan (scientific research), penggunaan pribadi (private use), dan penggunaan kutipan untuk laporan kejadian terkini (reporting current events), bahkan negara memungkinkan pembebanan lisensi sukarela (voluntary licenses) dengan tetap memperhatikan norma three step test. (Jened, 2014: 208)

Prinsip dasar daripada pembatasan dan pengecualian ini mempersyaratkan bahwa pembatasan dan pengecualian yang terdapat dalam legislasi masing-masing Negara didasarkan pada kasus-kasus spesifik yang dalam pemanfaatannya tidak meniimbulkan konflik dengan kepentingan dari pemegang hak cipta secara wajar/normal. (Jened, 2014: 208)

Youtube mendefiniskan bahwa penggunaan yang diperkenankan adalah pernyataan hukum yang menyatakan bahwa pengguna dapat menggunakan kembali materi yang dilindungi hak cipta dalam kondisi tertentu tanpa perlu memperoleh izin dari pemilik hak cipta.Di Amerika Serikat, penggunaan yang diperkenankan hanya bisa ditentukan oleh pengadilan. Pengadilan mengandalkan 4 (empat) faktor 
untuk menganalisis penggunaan yang diperkenankan menurut kasus per kasus, antara lain : (https://support.google.com/yout ube)

a. Tujuan dan karakter penggunaan, termasuk apakah penggunaan bersifat komersial atau untuk tujuan pendidikan non profit

Pengadilan biasanya berfokus pada apakah penggunaan tersebut bersifat "transformatif" atau tidak. Artinya, apakah penggunaan menambahkan ekspresi atau makna baru pada materi asli, atau hanya salinan dari aslinya. Penggunaan komersial kemungkinan kurang dianggap sebagai penggunaan wajar, meskipun monetisasi video masih mungkin dilakukan dan penggunaan salah satunya masih dapat dianggap sebagai penggunaan wajar.

b. Sifat dari karya berhak cipta menggunakan materi dari karya faktual dapat dianggap sebagai penggunaan wajar dibanding menggunakan karya fiksi.

c. Jumlah dan banyaknya porsi yang digunakan terkait dengan karya berhak cipta secara keseluruhan Meminjam sebagian kecil materi dari karya aslinya lebih dapat dianggap sebagai penggunaan wajar dibandingkan dengan meminjam sebagian besar. Namun, bahkan pengambilan sejumlah kecil dapat membatalkan penggunaan wajar dalam beberapa keadaan, jika yang digunakan merupakan "inti" dari karya.

d. Pengaruh penggunaan terhadap potensi pasar atau nilai karya berhak cipta Penggunaan yang merugikan kemampuan pemilik hak cipta untuk mendapatkan keuntungan dari karya aslinya, cenderung tidak dianggap sebagai penggunaan wajar. Pengadilan terkadang membuat pengecualian berdasarkan faktor ini dalam kasus yang melibatkan parodi.

Hal ini menuai banyak kritik dari berbagai kalangan salah satunya dari seorang Lawyer bernama Taylor B. Barthlolomew (https://www.pepperlaw.com/peo ple/taylor-b-bartholomew/L, yang tergambung dalam Asosiasi Pepper Hamilton LLP Attorney at Law, yang membuat suatu jurnal khusus mengenai Content ID ini. Jurnal tersebut berjudul "The Death of Fair Use in Cyberspace : Youtube And The Problem With Content ID". (https://dltr.law.duke.edu). Di dalam jurnal tersebut Taylor mengungkapkan bahwa terdapat permasalahan pada Content ID yang mana sistem tersebut tidak dapat memilah dan memilih konten mana yang memang benarbenar melanggar hak cipta, dan konten mana yang masih dalam batasan -batasan untuk tidak disebut sebagai pelanggaran hak cipta. Hal ini di akibatkan oleh cara dari Content ID itu sendiri bekerja yang hanya mencocokkan konten yang di upload

\section{KESIMPULAN}

Berdasarkan hasil penelitian yang telah dilakukan oleh penulis, dapat disimpulkan bahwa kriteriakriteria pembatasan hak cipta lagu dalam praktik covering melalui 
Youtube berdasarkan terms and conditions yang terdapat dalam peraturan internal Youtube adalah

(1) Tujuan dan karakter penggunaan, termasuk apakah penggunaan bersifat komersial atau untuk tujuan pendidikan non profit. Pengadilan berfokus pada apakah penggunaan tersebut bersifat "transformatif" atau tidak. Artinya, apakah penggunaan menambahkan ekspresi atau makna baru pada materi asli, atau hanya salinan dari aslinya. Penggunaan komersial kemungkinan kurang dianggap sebagai penggunaan wajar, meskipun monetisasi video masih mungkin dilakukan dan penggunaan salah satunya masih dapat dianggap sebagai penggunaan wajar.Ketentuan ini menjelaskan bahwa penggunaan suatu konten dapat di anggap sebagai penggunaan yang wajar (fair use) selama tidak mengubah substansi dari suatu konten tersebut, dan penggunaan untuk tujuan komersial kemungkinan tidak dianggap sebagai penggunaan yang wajar. (2). Sifat dari karya berhak cipta itu sendiri. Menggunakan materi dari karya dengan konten yang sudah ada pada database sebelumnya.

Faktual dapat dianggap sebagai penggunaan wajar dibanding menggunakan karya fiksi. Karya faktual adalah karya yang nyata baik yang terjadi di masa lampau atapun masa sekarang, sementara karya fiksi maksudnya adalah karya yang bersumber dari imajinasi.(3). Jumlah dan banyaknya porsi yang digunakan terkait dengan karya berhak cipta secara keseluruhan. Meminjam sebagian kecil materi dari karya aslinya lebih dapat dianggap sebagai penggunaan wajar dibandingkan dengan meminjam sebagian besar. Namun, bahkan pengambilan sejumlah kecil dapat membatalkan penggunaan wajar dalam beberapa keadaan, jika yang digunakan merupakan "inti" dari karya. (4). Pengaruh penggunaan terhadap potensi pasar atau nilai karya berhak cipta. Penggunaan yang merugikan kemampuan pemilik hak cipta untuk mendapatkan keuntungan dari karya aslinya, cenderung tidak dianggap sebagai penggunaan wajar.Keterangan di atas menandakan bahwa apabila penggunaan suatu karya tersebut digunakan dengan menkomersialkan ataupun memonitiosasinya, maka hal tersebut tidak termasuk sebagai penggunaan yang wajar.

\section{DAFTAR PUSTAKA}

17, R. (2017, November 20). Mengenal Bagian-Bagian Dalam Sebuah Lagu. Diakses Agustus 27, 2018, dari https://steemit.com/indonesia/@ rial17/mengenal-bagian-bagiandalam-sebuah-lagu

Ashibly. (2016). Hukum Hak Cipta : Tinjauan Khusus Performing Rights Lagu Indie Berbasis Nilai Keadilan. Yogyakarta: Genta Publishing. Atmaja, H. T. (2004). Hak Cipta Musik atau Lagu. Jakarta: UI Press. 
Audah, H. (2004). Hak Cipta dan Karya Cipta Musik. Malang: PT. Litera Antar Nusa.

Auteurswet 1912 tentang Hak Cipta

Barthlolomew, T. B. (2015, Maret 15). The Death of Fair Use In Cyberspace : Youtube and The Problem With Content ID. Diakses September 3, 2018, dari Duke Law and Technology Review: https://dltr.law.duke.edu/2015/0 $3 / 15 /$ the-death-of-fair-use-incyberspace-youtube-and-theproblem-with-content-id/

Barthlolomew, T. B. (2019). Pepper Hamilton LLP Attorney Law. Diakses September 3 , 2018, dari

https://www.pepperlaw.com/peo ple/taylor-b-bartholomew

Djumhana, M., \& Djubaedillah, R. (1997). Hak Kekayaan Intelektual (Sejarah Teori dan Prakteknya di Hanin Dhiya, d. d. (2017, Oktober 1). Klarifikasi dan Permohonan Maaf. Diakses Oktober 4 , 2018, dari

https://www.youtube.com/watch? $\mathrm{v}=\mathrm{IGg}-2 \mathrm{i} 4{ }_{-} \mathrm{N}_{-} \mathrm{Y}$

Hasibuan, O. (2007). Hak Cipta di Indonesia Tinjauan Khusus Hak Cipta Lagu, Neighbouring rights, dan Collecting Society. Bandung: PT. Alumni.

Hasyim, M. I. (2008, Maret 2). Perlindungan Hak Cipta Bagi Pengunggah Video Youtube Yang Digunakan Oleh Stasiun Televisi.
Jurnal Hukum, 2 ( 2). November 3, 2018, dari repository.unhas.ac.id/handle/123 $456789 / 3695$

Hidayah, K. (2017). Hukum HKI. Malang: Setara Press.

Hukum dan Perlindungan Hak Cipta. (2003). Jakarta: CV. Novindo Pustaka Mandiri.

Indonesia). Bandung: Citra Aditya Bakti.

Jened, R. (2014). Hukum Hak Cipta. Bandung: PT. Aditya Bakti.

Kamil, A. (2017, September 27). Lagu Akad Di-cover dan Dijual, Payung Teduh Keluarkan Peringatan. Diakses Oktober 4, 2018, dari https://entertainment.kompas.co $\mathrm{m} / \mathrm{read} / 2017 / 09 / 27 / 173822010$ /lagu-akad-di-cover-dan-dijualpayung-teduh-keluarkanperingatan

Komentar Undang - Undang Hak Cipta. (2016). Bandung: PT. Alumni.

Konvensi Bern 1886

Konvensi Hak Cipta Universal 1955

Konvensi Jenewa 1971 tentang Perlindungan Produser Rekaman Suara dan Perbanyakan sah Rekaman

Konvensi Roma 1961 tentang Perlindungan Pelaku, Produser Rekaman, dan Lembaga Penyiaran Margono, S. (2010). Hukum Hak Cipta Indonesia: Teori dan Analisis 
Harmonisasi Ketentuan World Trade Organization-TRIPs Agreement. Jakarta: Ghalia Indonesia.

Muhammad, A. A. (2017). Konvensi International Tentang Hak Cipta dan Pengaturan Hak Cipta di Indonesia. Al-Qisth Law Review, 1 (7). November 4, 2018. https://jurnal.umj.ac.id/index.php Lal-qisth/article/view/1690

Nainggolan, B. (2011). Pemberdayaan Hukum Hak Cipta dan Lembaga Manajemen Kolektif. Bandung: PT. Alumni.

Official Alan Walker Twitter. (2015, Desember 21). Diakses September 4, 2018, dari https://twitter.com/iamalanwalke r/status/679109558921469952

Peraturan internal Youtube Terkait Konten Berhak Cipta. September 10, 2018. https://support.google.com/youtu be/?hl=id\#topic=7505892

Persetujuan Aspek Perdagangan Terkait dengan Hak-Hak Kekayaan Intelektual (TRIPs Agreements) WIPO Copyright Treaty

Rawlinson, K. (2018, Juli 22). Youtube Star Michelle Phan Sued Over Copyright Breach. Diakses Juli 30 , 2018, dari BBC News: https://www.bbc.com/news/tech nology-28418449

Riswandi, B. A. (2009). Hak Cipta Di Internet: Aspek Hukum Dan
Permasalahannya Di Indonesia. Yogyakarta: FH UII Press.

Sardjono, A. (2009). Membumikan HKI di Indonesia. Bandung: CV. Nuansa Aulia.

Sitorus, R. (2006). Pembayaran Royalti Kepada KCI Sebagai Kompensasi Penggunaan Hak Mengumumkan Lagu Beserta Permasalahannya. Jakarta: Tesis Program Pasca Sarjana Universitas Indonesia.

Soemitro, R. H. (1988). Metodologi Penelitian Hukum dan Juiri Metri. Jakarta: Ghalia Indonesia.

Syarifuddin. (2013). Perjanjian Lisensi dan Pendaftaran Hak Cipta. Bandung: PT. Alumni

Tanjung, K. H. (2007). Hak Kekayaan Intelektual. Jakarta.

Undang-Undang No. 19 Tahun 2002 tentang Hak Cipta

Undang-Undang No. 28 Tahun 2014 tentang Hak Cipta 